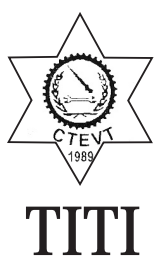

Journal of

Training and Development

2020, Volume 5

ISSN: 2392-456X(Print)

ISSN: 2392-4578(Online)

DOI: https://doi.org/10.3126/jtd.v5i0.33847

\title{
Developing a Typology of Informal Skills Learning Places in Nepal
}

\author{
Durga Prasad Baral \\ PhD Research Fellow \\ Kathmandu University, School of Education \\ Hattiban, Lalitpur, Nepal \\ Email for Corresspondance : baraldurga@kusoed.edu.np
}

\begin{abstract}
The dominant category of the labour forces of Nepal are the workers from the informal sectors where basically informal skills learning occurs during the work. However, informal skills learning is not only limited to informal sector jobs. It can take place in all types of organizations, enterprises, and institutions of both formal and informal sectors. It is estimated that more than eighty percent of workers in Nepal acquire their occupational skills during their work. However, it is not evident what are the typologies of working places of those informal skills learners. Taking a qualitative approach of inquiry, this paper analyses the existing legal frameworks and literature from domestic cultural practices. Based on this analysis, it presents a typology of informal skills learning places in Nepal developed mainly considering the points prescribed by Bailey (1994). It is claimed that the typology provides a sound conceptual basis for the identification of main categories and subcategories of informal skills learning places in Nepal.
\end{abstract}

Keywords: Informal skills learning place, typology, informal employment

\section{Introduction}

The informal sector is a dominant economic sector of Nepal where more than 80 percent of the total workforce is involved (Ministry of Labour and Employment [MoLE], 2014; World Bank, 2019). Workers working in this sector generally acquire occupational skills during their work. However, such learning is not only limited in the informal sectors but also happens in other workplaces such as government, non-government, private sector business and industry, etc. Informal skills learners are the workers, either working in the informal or formal sectors who learn skills during the work.
Informal skills learning place is the employment entity, whether formal or informal, in which a person works and learns work-related skills as well as soft skills such as dealing with customers and working in a team.

The dimension of the informal economic sector and consequently the informal skills learning is broad in Nepal but it is a less researched area (International Labor Organization [ILO], 2004). A recent study on labour market in the four occupational sectorsagriculture, engineering, health, and hospitality by the Council for Technical Education and Vocational 
Training (CTEVT) also did not cover informal employment in the informal sector (Council for Technical Education and Vocational Training [CTEVT], 2016).

Some studies about the Technical and Vocational Education and Training (TVET) sector in Nepal show the prevalence and importance of experiential learning (Regmi, 2009; Adhikary, 2012; Dhungel, 2014). But the typology of those experiential or informal skills learning places is not yet developed. The mapping of such informal skills learning places can be instrumental to reduce the disparity in providing educational and training opportunities to youth and support to broaden the skills assessment and certification activities in the country.

In this context, this paper provides a sketch of informal skills learning places in Nepal. Particularly, it provides a typology that helps to understand the informal skills learning places and their formality. This would ultimately support on achieving goals of increasing access of interested people to TVET and making TVET Funds efficient by minimizing training costs (Government of Nepal [GoN], 2012).

After providing a brief overview of the introduction and use of typology, some examples of typology in the sector of TVET will be presented. Then, I will present methods and techniques for developing a typology and present the developed typology of informal skills learning places in Nepal. Finally, the paper concludes with reflections and implicates for future researchers.

\section{What and Why of Typology}

Typology is commonly used in day to day life. Even farmers, labourers, and social workers use typology in their daily informal communications. For instance, a farmer understands and expresses the type of farmland (according to its fertility, irrigation viability, and other experience-based criteria) and suitable crop (vegetable, grains, or fruits) for cultivation. An artisan can have a list of appropriate tools for performing a particular work. Similarly, a social worker can make a strategy to deal with people depending upon their social background and educational status. In this sense, typology is a "classification" (Bailey, 1994, p. 2) of the phenomena based on certain relational variables which are understood as "ordering of entities into groups or classes on the basis of their similarity" (p.1).

The main purpose of a typology is to present a simplified picture of a complex phenomenon for preparing an analytical tool. Such a tool helps in comparing and mapping empirical information. It is a tool for systemic analysis that can act as a "bridge" (Collier et al., 2008, p. 162) between quantitative and qualitative research which helps to make a comparison between quantitative and qualitative information. The scope and use of typology are broad. In the following section, I present some examples of typologies from the field of technical and vocational education and training.

\section{Typologies and its Use in TVET Sector}

Typologies are used in various sectors including Technical and Vocational Education and Training (TVET). Some examples are a typology of work experience developed by David Guile and Toy Griffith (2001); typology of knowledge, skill and competency by the European Centre for the Development of Vocational Training [CEDEFOP] (2006), and typology of training funds developed by Johanson (2009). The typology developed by Guile and Griffith (2001) is presented in a matrix that contains five different models of work experience-traditional, experimental, generic, work process, and cognitive - in columns, and six different features of work experience in the rows. Those features include purpose of work experience, assumption about learning and development, practice of work experience, management of work experience, outcome of work experience, and role of education and training provider. Thus the typology provides thirty different cases based on the individual cells of the matrix, which helps in identifying these cases, based on the particular context.

Similarly, the typology of knowledge, skill, and competency developed by CEDEFOP with the 
involvement of trio-scholars Jonathan Winterton, Francoise Delamare-LeDeist, and Emma String is also presented in a matrix with three columns of knowledge, skills and competencies, and attitudes, which are standardized from level one to eight (CEDEFOP, 2006; p. 62). This typology formation was performed based on three major steps. The first step was the identification of the description of the elements. The next step was the specification of the terminologies used. Finally, the typology was developed including its utility in Europe and other countries. This typology is practical and presented in a simple matrix but difficult to translate at the implementation level (CEDEFOP, 2006). In this sense, even a typology is comprehensive and clear, contextualization is necessary for its effective use. The other example of typology, developed by Richard
Johanson (2009), is related to training funds based on the review of more than sixty countries implementing pre-employment and enterprise training funds. The typology highlights good practices in technical and vocational education and training; and addresses training fund designing issues. Further, it presents a training fund as an international issue (Johanson, 2009). The typology developed is presented in a three by two matrix. The rows contain the pre-employment training fund, enterprise training fund, and equity training fund whereas the column displays the main purpose and financing sources of these training (Table. 1). The typology is very simple and provides a clear description of training funds and their characteristics that have made it usable by policymakers and planners working in the area of fund planning and management.

Table. 1

A Typology of Training Funds

\begin{tabular}{llll}
\hline S.N. & Type & Main Purpose & Financing Sources \\
\hline 1. & Pre-employment Training Fund & $\begin{array}{l}\text { Finance the expansion and delivery } \\
\text { of initial training before } \\
\text { employment }\end{array}$ & $\begin{array}{l}\text { Payroll levy-revenue } \\
\text { generating }\end{array}$ \\
& &
\end{tabular}

2. Enterprise Training Fund

3. Equity Training Fund
Proivde incentives to increase inservice training of workers within enterprises

Increase opportunities for skills acquisition by disadvantaged groups not covered by enterprise
Payroll levy - incentive schemes

Public subsidy, levy or donors

Source: Johanson, 2009

Based on these typologies, it can be perceived that typologies are prepared according to a need for presenting an analytic framework or systematization of information. However, there is a debate among scholars on common procedures and techniques for preparing typologies. In this regard, the following section briefly presents some global concepts and methods of developing a typology.

\section{Typology Formation Methods and Techniques}

Literature on typology development supports that the method of developing typology depends on the purpose of typology and its use. Furthermore, the context where the typology is to be used is also a primary concern of typology formation (CEDEFOP, 2006). The major points to be considered during the preparation of a typology is the maintenance of the minimization of "within-group homogeneity" and maximization of "between-group heterogeneity" (Bailey, 1994, p. 1). It means that a typology should be designed in such a way that there should not be a chance of repetition or overlapping of the particular category of information. For the successful typology development, the main requirement is the "ability 
to ascertain the key or fundamental characteristics on which the classification is to be based" (Bailey, 1994, p. 2). However, this is not always possible. Probably one of the reasons that the developer of typologies, mainly qualitative one, have to face the criticism that they develop "simplistic classification systems” (Doty \& Glick, 1994, p. 230).

Considering these main features, I analyzed and developed the typology of informal skills learning places in Nepal. In the following section, I present the basis of developing this typology.

\section{Typology of Informal Skills Learning Places in Nepal}

Informal learning can happen everywhere since it "takes place in the daily work situation" (Kyndt et al., 2009; p. 370). Furthermore, it can occur in every type of work setting and provision. So, there is a challenge of incorporating every probable case while preparing a typology as there should be an appropriate place assigned for each probable individual case.

Generally, typologies are constructed using rows and columns with assigned cells to each probable category (Bailey, 1994). Following a similar kind of approach, I have constructed typologies using rows and columns but in a slightly different way. The difference is that the number of sub-categories under each category is not identical. For instance, among the five categories, four have five subcategories each while one category only has two sub-categories. These categories and sub-categories of informal skills learning places are made according to the existing legal frameworks related to employment and social practices which aremodernity of the occupational sector employed, size of employing enterprise, regularity of employment, industry sector of employment, and governance of employing organization. Albeit Nepal Standard Industrial Classification (NSIC) categorises economic and industrial activities under different 21 sections, 238 groups, and 419 classifications (Central Bureau of Statistics [CBS], 2019), they can be fitted under these five categories and their subsequent subcategories.

Besides the categories and sub-categories of informal learning places, the typology also provides a tentative direction of increment and decrement of formality of such learning places (of employment). For this, sub-categories under each category of informal skills learning are placed in sequential increasing order of formality from right to the left (Table. 2).

In the following section, I have provided the major categories and their subsequent sub-categories that are incorporated in the typology.

\section{Category-1: Modernity of Occupational Sector Employed}

In Nepal, traditional occupational practices are being transferred from generation to generation (Kafle, 2007). These practices are rooted in the occupational classification based on the caste-system. However, in recent decades, people are shifting their occupations to a newly emerged area such as manufacturing and services. Such newly emerged occupations are either called non-traditional or modern (Asian Development Bank [ADB], 2009). Thus, in broader categorical classification, there are mainly:

Sub-category-1. Modern occupations

Sub-category-2. Traditional occupations 
Table 2

A Typology of Informal Skills Learning Places in Nepal

\begin{tabular}{|c|c|c|c|c|c|}
\hline $\begin{array}{l}\text { Sub-category } \\
\text { Category } \\
\text { based on }\end{array}$ & 1 & 2 & 3 & 4 & 5 \\
\hline $\begin{array}{l}\text { 1. Modernity of } \\
\text { occupational sector }\end{array}$ & \multicolumn{3}{|c|}{ Modern and Traditional } & & \\
\hline $\begin{array}{l}\text { 2. Size of employing } \\
\text { enterprise }\end{array}$ & Big & Medium & Small & Cottage & Micro \\
\hline $\begin{array}{l}\text { 3. Regularity of } \\
\text { employment }\end{array}$ & Regular & Part-time & Time-bound & Work-based & Casual \\
\hline $\begin{array}{l}\text { 4. Industry sector of } \\
\text { employment }\end{array}$ & $\begin{array}{l}\text { Professional/ } \\
\text { Admin }\end{array}$ & $\begin{array}{l}\text { Tourism and } \\
\text { hospitality }\end{array}$ & Manufacture & $\begin{array}{l}\text { Construction } \\
\text { and water- } \\
\text { supply }\end{array}$ & $\begin{array}{l}\text { Agroforestry } \\
\text { and mining }\end{array}$ \\
\hline $\begin{array}{l}\text { 5. Governance of } \\
\text { employing } \\
\text { organization }\end{array}$ & $\begin{array}{l}\text { Governement } \\
\text { (Civil) }\end{array}$ & $\begin{array}{l}\text { Government } \\
\text { (Other) }\end{array}$ & $\begin{array}{l}\text { Corporate } \\
\text { bodies }\end{array}$ & $\begin{array}{l}\text { Private- } \\
\text { formal }\end{array}$ & $\begin{array}{l}\text { Private- } \\
\text { informal }\end{array}$ \\
\hline High & & $\begin{array}{l}\text { Formal } \\
\text { employ }\end{array}$ & $\begin{array}{l}y \text { of } \\
\text { nent }\end{array}$ & & Low \\
\hline
\end{tabular}

These modern and traditional occupations (category1) cover all economic sectors. So, rather than providing individual cells for both sub-categories (modern and traditional occupations), they are placed in the same cell in the typology which shows the existence of these occupational sectors under each other categories (category 2, 3, 4 and 5). As most of the traditional occupational practices are under the informal economic sector, this is the dominant employment area in Nepal. Although disaggregated data on the number of workers employed in the traditional and modern occupational areas is lacking, a recent report of Nepal Labour Force Survey 201718 indicates the dominance of the employment in Agriculture, Forestry and Fishing (more than onefifth of the total employment) (CBS, 2019; p.20), which is basically based on traditional occupations. Furthermore, traditional occupations are also in other sectors such as mining and quarrying as well as construction. Thus, the size of traditional occupational employment is big. Similarly, in different other occupational sectors considered as modern such as manufacturing, motor vehicle and motor parts, accommodation and food services, education, the proportion of employment is considerable.

\section{Category-2: Informal Skills Learning Places as per Size of Employing Enterprise}

This category of informal skills learning places is based on the size of occupational enterprises. In Nepal, according to the recently amended Industrial Enterprise Act, 2073 (2016); enterprises and industries are classified into five different types; microenterprises, cottage industry, small industry, medium industry, and big industry (GoN, 2016; p.5). Based on this provision, informal skills learning places under this category are sub-categorised as following: 
Sub-category-1. Big Industry.

Sub-category-2. Medium industry

Sub-category-3. Small industry

Sub-category-4. Cottage industry

Sub-category-5. Micro-enterprises

As defined by the Industrial Enterprise Act, 2073, the first sub-category is Big Industry. The industries and corporate houses under this subcategory are on a big-scale. The Act provisions such industries that have permanent capital of more than 250 million Nepali Rupees. Similarly, the second sub-category is the Medium Industry which has a fixed capital of 100 to 250 million Nepali Rupees. Likewise, the third sub-category is Small Industry (except micro and cottage industries) with fixed capital up to 100 million Nepali Rupees. Finally, the fourth and fifth sub-categories defined by the Act are the Cottage Industry and Micro-Enterprise respectively. These two types of industries and enterprises have some additional provisions except the ceiling of fixed capital. For instance, a micro-enterprise has a maximum of 500 thousand Nepali Rupees fixed capital and can have a annual turn-over of five million Nepali Rupees. The act also conditions the proprietor to work as a worker and can hire a maximum of nine employees. The cottage industry is not defined by the fixed capital and annual turn-over but it is specified according to the skills, raw materials, and tools/equipment used. Furthermore, the act guides cottage industries and desires such industries to follow traditional skills and adopt local technology. Likewise, the industry should be based on local resources, arts and culture; and the capacity of machinery and equipment should not be more than ten kilowatts (GoN, 2016; p.5).

The subcategories (1-5) are placed from left to right where the formality of employment decreases accordingly. Here, the characteristics of formality are estimated based on practice and legal provisions. The main differences between the formal and informal economy, as ILO (2004) defines, are based on certain practices and provisions. In the formal economic sector, formal contracts for the appointment of the workers are made stating their wages or salaries, working hours as well as other benefits. Whereas in the informal economy, such practice of formal contracts are generally not expected. The terms and conditions such as rates and work-hour are agreed verbally if any. Legal protection provisions are either lacking or very poor (ILO, 2004) in such employments. Thus, in informal enterprises the industries are not registered, employments are rarely contract-based and terms and conditions are mostly verbal.

\section{Category-3: Informal Skills Learning Places as per Regularity of Employment}

According to the Labour Act 2017, work is classified into five types based on the regularity of employment: regular, part-time, time-bound, work-based, and causal (MoLE, 2017). According to this classification, the following sub-categories of informal skills learning places are made under this category.

Sub-category-1. Niyamit [Regular] Employment The employments which are based on utilizing the full time of a worker, as specified by the rule, is classified as Niyamit [Regular] employment. Generally, working youth aim for such regular employment because such employments are associated with benefits. However, such employment opportunities are limited in Nepal due to the dominance of the informal sector where more than half of the workers are estimated to be employed on a part-time basis (CTEVT, 2016). Hence, this subcategory of Regular Employment is placed on the left edge of the typology.

\section{Sub-category-2. Ansik [Part-Time] Employment}

The employments which are for a short duration (35 hours or less in a week) are taken as Ansik [parttime] employment (MoLE, 2017). Though there is a scarcity of literature which explains the perception of people towards such part-time jobs, overall Jagire mentality (desire for white-collar civil service mentality) of people and perception of the society towards labourers as low-level workers (Baral, 2019, 
Bista, 1991; Bhattarai, 2017) support for putting this sub-category in the right side of the sub-category1 (full-time employment) in the typology.

\section{Sub-category-3. Samayagat [Time-Bound] Employment}

In this sub-category, the employment is for a certain period of time with the objective of completion of a particular work or service, and it is thus classified as Samayagat [time-bound] employment (MoLE, 2017). As such provisions are generally in the informal sectors, this is placed right to the subcategory-2 (part-time employment).

\section{Sub-category-4. Karyagat [Work-Based] Employment}

Similarly, employment that is based on the completion of a specific task is taken as Karyagat [work-based] employment (MoLE, 2017). The major difference between Samayagat and Karyagat employment is the type of work agreement. If a person is hired for a certain period to execute a certain work, it is considered as time-bound employment. On the contrary, work-based employment is based on the contract with a specified period with the obligation of completion of a particular work.

\section{Sub-category-5. Akasmik [Causal] Employment}

The employment which is not foreseen and provisioned for a very short period is known as causal employment. According to the Labour Act 2074, the duration of such employment is of seven days or less within a month (MoLE, 2017).

Although disaggregated data on the size of workers under these sub-categories is unavailable, the bigger size of job-seekers (69 percent) who were searching for a job for less than a year (CBS, 2019) indicates that most of the unemployed youth had the job of temporary nature. Thus, the sequence of subcategories under this category from left to right is placed in the sequence of regular, part-time, timebound, work-based, and causal.
Category-4: Informal Skills Learning Places according to the Industry Sector of Employment The industry sector also provides space for informal learning. National Employment Policy Nepal, 2014 classifies six employment sectors - agriculture, manufacturing, construction, tourism, information and communication technology, and water resources and energy (MoLE, 2014). Accordingly, Labor Force Survey 2017-2018 provides an approximate cluster of different industry sectors employment. However, disaggregated information on the size of employment in these areas is lacking. Based on the headings in the Labor Force Survey, I clustered 21 industry sectors (CBS, 2019; p. 20) under the five main subcategories. In the typology, these sub-categories are sequenced in decreasing order of formality from left to right.

\section{Sub-category 1. Professional and Administrative Sector}

This sub-category includes eight different industry sectors of employment including Information and Communication Technology (ICT). Among the seven million employed population in Nepal, 15 percent are employment under this sub-category. It comprises of information and communication technology; electricity, gas, steam, and air conditioning supply; professional, scientific and technical activities; administrative and support service activities; public administration and defense, education, human health, and social work, and activities of extraterritorial organizations and bodies (CBS, 2019; p.20).

Among these sub-categories, the ICT sector is growing at a large scale despite its insufficient resources and infrastructure (Sharma, 2016). Information and Communication Technology (ICT) Policy, 2072 (2015) also recognizes the increased need and interest of people on ICT provisions for making it affordable and accessible to all citizens (Ministry of Information and Communication [MoIC], 2015). In this sense, it can be said that the aspiration of Nepali people toward ICT is growing rapidly. All the employments under this sub-category 
are more associated with the formal sector and thus they are placed on the very left side of the category.

\section{Sub-category 2. Tourism and Hospitality Sector}

The tourism and hospitality sector is a growing sector in Nepal. Among the total 21 industry sectors, four are included under this sub-category which sums 7.6 percent of total employed people (Ministry of Culture, Tourism and Civil Aviation [MoCTCA], 2015). It includes accommodation and food service activities; arts, entertainment and recreation; real estate activities. To make the typology, the financial sector including real states and insurance activities are also put under this sub-category.

According to the survey report of Ministry of Culture, Tourism and Civil Aviation 2015, the tourism sector covers enterprises that range from very small informal hotels, restaurants, and home-stays to organized international standard star hotels where more than 138,141 people are employed MoCTCA (2015). Tourism is also a "significant contributor to employment generation and foreign exchange earnings" (p. XI). Considering comparatively higher employment in the formal sector, this sub-category is put second in order, left to the sub-category-1: professional and administrative sector.

\section{Sub-category 3. Manufacturing, Trade and Service Sector}

The manufacturing sector of Nepal has not flourished yet. Among many reasons, continuous shortage of electricity supply, as well as the unstable political situation of the country, are among the main reasons for this (Supporting Economic Transformation [SET], 2017). Nevertheless, this sector is still one of the major employment sectors, particularly for seasonal and part-time works. According to the Labour Force Survey, 2017/18, the size of the employed people in the manufacturing sector is 15 percent (CBS, 2019; p.20). In addition to the manufacturing sector, the other three industry sectors-wholesale \& retail trade, repair of motor vehicles \& motorcycles (17.5 percent); transportation and storage (4.5 percent); and other service activities (2.2 percent) are also included in this sub-category. Thus, this sub-category which covers 39.4 percent of all employment, is the biggest in the category of manufacturing, trade and service.

\section{Sub-category 4. Construction and Water-Supply Sector}

The construction sector is a growing economic sector of the country which employs about one-seventh (13.8 percent) of the total workforce (MoLE, 2014; CBS, 2019). In this typology, employment in the water-supply industry is also put under this subcategory which has a share of 0.6 percent in total (CBS, 2019; p.20). Thus, this sub-category covers 14.4 percent of the total employment. The modern construction technology is gradually being introduced, however, the traditional informal practice of construction is still prevailing in the residential building construction. Though there is a high demand for skilled workforce in this sector, it is still prevalent of low and semi-skilled workers who generally lack educational opportunity (CTEVT, 2016).

\section{Sub-category 5. Agro-Forestry, Mining, and Private Household Sector}

Though the agriculture sector in Nepal is shrinking in recent years, it is still one of the major contributors which shares more than one fourth (27.6 percent) of the GDP (Ministry of Finance [MoF], 2018, p. 3). Similarly, this sector which includes agriculture, forestry and fishing industry is a big employment provider. The sector shares 21.5 percent of the total workforce of the country (CBS, 2019; p.20). However, mostly, agricultural occupational activities are limited to the traditional practice of subsistence farming. Normally, people engaged in this occupational sector are informal workers, this subcategory is placed in the last (fifth in order) from the left side of the typology. Besides agriculture, forestry and fishing other two industrial sectors mining and quarrying are also included in this subcategory. Thus, this sub-category has a total share of 23 percent of the total employment. 


\section{Category-5: Informal Skills Learning Places according to the Governance of Employing Organizations}

Some legal frameworks such as the Constitution of Nepal (GoN, 2015), Public Service Commission Act, 2066 (GoN, 2010), Local Self Governance Act (GoN, 1999) support to classify the employing organizations into five main sub-categories, which are as follows:

\section{Sub-category-1. Government Organizations (Civil Service)}

Public Service Commission (PSC) is a statutory body established and operated by the provision of the Constitution of Nepal ( 2015). Civil service employees are selected, appointed, and promoted by the Public Service Commission through intensive evaluation in the recruitment process. According to the recent data of the Ministry of General Administration, there was slightly more than 80 thousand civil servants' position on the eve of the state's restructuring process. However, the number has been frequently changing along with the reformation of the governance structure in the past. This number has been remaining in around 100 thousand (Ministry of General Administration [MoGA], 2014) which is considerably less in comparison to the size of the total workforce of the country which is 7.1 million(CBS, 2019).

\section{Sub-category-2. Other Government Organizations} Other government organizations are mainly the national security organizations such as Nepal Army, Nepal Police, and Armed Police Force. The Public Service Commission is involved in the process of recruitment and promotion of employees of such organizations (GoN, 2010; GoN, 2015). Similarly, the employees in the community schools and universities are appointed by an independent commission formed by the government (Teachers Service Commission [TSC], 2019; TU-Service Commission, 2019) with the involvement of the Public Service Commission (PSC, 2015). Employees of other institutions such as technical schools and polytechnics can also be placed under this subcategory.

As this sub-category includes all national security forces as well as teachers of community schools, colleges, and universities, the number of employees in this sub-category is larger than in civil service (sub-category-1). The number of teachers (receiving a salary from the public fund) only is around 150 thousand (Ministry of Education [MoE], 2018) which is more than the size of civil servants.

\section{Sub-category-3. Corporate Bodies}

The constitution of Nepal, 2015 under the section23 on Public Service Commission mentions about "Corporate Bodies". The corporate body includes corporations, authorities, councils, and other similar organizations. It is relevant to incorporate such organizations under this sub-category since the government shares more than 50 percent in the establishment and operation. The employees in these organizations are selected, appointed and promoted according to their legal frameworks which align with the provision of the Public Service Commission (GoN, 2015). Furthermore, this sub-category also includes the employees who are appointed in the local government units according to the previous Local Self-Governance Act, 1999, and present Local Government Operation Act, 2074 that substitutes the previous provisions of the Act (GoN, 1999; MoLE, 2017).

\section{Subcategory-4. Formal Private Organizations} Organizations and institutions running in the formal private sector such as business, industry and enterprises are categorized under this sub-category. Generally, the selection, appointment and promotion of the employees in such organizations are performed according to their institutional procedures and guidelines. The nature of management in these organizations is flexible though they follow general guidelines provided by the Government (GoN, 2019). This sub-category also includes national and international non-governmental organizations (NGOs), as these formal organizations are also 
functioning with little control and guidance of the government (United Nations Development Program [UNDP], 2019)

\section{Subcategory-5. Informal Private Organizations}

These organizations are generally not registered in the government system. Selection, appointment, and promotion are made based on the verbal agreements between the owner and the employee (ILO, 2004). As the informal private sector is the dominant economic sector of Nepal (World Bank, 2019), the size of this sub-category of informal skills learning place in the typology is the largest of all.

The high competition in the recruitment process of employees' in the Public Service Commission, Teachers Service Commission, and security organizations shows that the attraction of youth for getting employment in such organizations is very high. In the year 2016/17, the number of applicants in the government positions was almost 100 times more than the advertised positions (Public Service Commission [PSC], 2018). One of the main reasons behind high attraction towards government employment is job security as the laws on civil service are "very protective" (The Asia Foundation, 2012, p. 15). Such attraction is associated with the social prestige provided by the society for such employments.

Though sub-categories except informal private organizations are formal, their sequencing from the left to right is made based on government employment. So, the sub-category of Government Organizations (as Civil Servants) is placed on the very left side of the typology and Other Government Organizations is placed next to it on the right side. Similarly, organizations under the sub-category of Corporate Bodies are placed next to the Other Government Organizations, and the other two remaining sub-categories-formal private organizations and informal private organizations are placed in the right edge of the category.

Thus, the developed typology includes five major categories and relevant sub-categories under four categories as mentioned in the above sections. One category of informal skills learning place— based on the modernity of the occupational sector- has only two sub-categories. The typology also tentatively presents the formality of the particular sub-category of the informal skills learning place. The formality of the employment (i.e. informal skills learning place) increases towards the left side and decreases as we move towards the right side of the typology. For instance, the Agro-forestry and mining sub-category under the category of 'Industry Sector of Employment' has less formality in comparison to the Professional and ICT sector which is placed at the left edge of the category.

\section{Reflections}

Despite the extensiveness of informal skills learning in Nepal, little is known as to where the learners actually learn their skills and work. This paper has presented a typology portraying the places of employment occurring informal skills learning under different categories and their subsequent subcategories. It also displays a tentative direction of increment and decrement of the formality of those employment places.

Informal skills learning is a less researched area in Nepal. This is the first attempt at preparing such typology. The TVET system of the country is expected to be benefitted from this typology as it will help in the identification of informal skills learning places and their inclusion in the policy provisions such as the development of national occupational skills standards (NOSS) and designing TVET courses focusing on that huge size of informal skills learners particularly working in the informal and traditional occupational sectors. Furthermore, TVET planners, managers, and general academicians and scholars are also expected to be benefitted from using the typology as an analytical tool.

However, this typology could have been even more comprehensive if sufficient information were available. One of the major challenges I faced while 
writing this paper was the lack of sufficient data on the categories and sub-categories of employment places which were included in the typology. Furthermore, the sequencing of the sub-categories under each category is done based on the nature of the individual category. For instance, under the category-3 'Regularity of Employment', time-bound employment is considered more formal than workbased which is not always the case. So, this sequencing of the sub-categories should be taken subjectively rather than comparing them objectively.

Nevertheless, it is claimed that this typology can serve as a sketch for the development of other typology in similar contexts and also for the enhancement and shaping of the informal skills learning places in Nepal in future. Association of this typology with social prestige obtained by the informal skills learners; and the educational qualification of learners can be another major field for future researchers.

\section{Acknowledgments:}

I thank the Swiss Agency for Development and Cooperation (SDC), the Swiss National Science Foundation, and SDC Nepal for financing the research. I am grateful for the inputs and support provided by Prof. Mahesh Nath Parajuli for the completion of this paper. I am also thankful to the scholars who provided feedback at the International Conference on Technical and Vocational Education and Training (ICTVET) held on 11-12 September 2019 in Dhulikhel, Nepal. I would like to thank Mr. Prakash Kumar Paudel, KUSOED, for his support in editing and framing the paper.

\section{Note}

This Paper is presented to International Conference on Technical and Vocational Education and Training (ICTVET),11-12 September 2019, at Dhulikhel, Nepal

\section{References}

Adhikary, P. K. (2012). Role of TEVT in reviving traditional arts, crafts and sculptures. Technical
Vocational Education and Training Development Journal, 12(1), 103-107.

Asian Development Bank [ADB]. (2009). Good practices in technical and vocational education and training. Manila: Author.

Bailey, K. D. (1994). Typologies and taxonomies: An introduction to classification techniques. New Delhi: Sage

Baral, D. P. (2019, November 20). Searching the Places of Informal Learning Places in TVET system of Nepal LELAM Working Papers, vol. 4, Zurich: KOF Swiss Economic Institute, ETH Zurich. Retrieved from ETH Zurich LELAM TVET4INCOME-an r4d research project: https://r4d. tvet4income.ethz.ch/publications/ working-paper-series.html

Bhattarai, A (2017). National Vocational Qualification Framework (NVQF) for Nepal: Necessity or waste of money? Experts' standpoint. Journal of Training and Development., 3, 3-11.

Bista, D. B. (1991). Fatalism and development: Nepal's struggle for modernization. Calcutta, India: Orient Longman.

CEDEFOP. (2006). Typology of knowledge, skills and competencies. Luxembourg: Author

CEDEFOP. (2007). Recognition and validation of non-formal and informal learning for VET teachers and trainers in the EU member states. Belgium: Author.

Central Bureau of Statistics [CBS]. (2019, August 5). Nepal Standard Industrial Classification. Retrieved from National Planning Commission, Central Bureau of Statistics: https://cbs.gov. $\mathrm{np} /$ nepal-standard-industrial-classification/

Central Bureau of Statistics [CBS]. (2019). Report on the Nepal Labour Force Survey 2017/18. Kathmandu: Author.

Collier, D., Laporte, J., \& Seawright, J. (2008). 
Typologies: Forming concepts and creating categorical variables. The Oxford Handbook of Political Methodology, 152-173.

Council for Technical Education and Vocational Training [CTEVT]. (2016). Labour force survey: Analysis of emerging needs of technical human resources in the country. Kathmandu: Author.

Council for Technical Education and Vocational Training [CTEVT]. (2018, August 17). About Us. Retrieved from Council for Technical Education \& Vocational Training [CTEVT]: http://ctevt.org.np/page.php?pagecat $=7$

Dhungel, D. (2014). Factors affecting recognition of experiential learning in Nepal. (Unpublished $\mathrm{PhD}$ dissertation). Southern Illinois University, Carbondale, USA.

Doty, D., \& Glick, W. (1994).Typologies as a unique form of theory building: Toward improved understanding and modeling.Academy of Management Review, 19(2), 230-251.

EAPRIL. (2019, October 17). Informal learning guide: A systematic mix-method study of learning analytics for informal learning in the workplace: The what, why and how. Retrieved from EAPRIL: https://www.eapril.org/sites/default/ files/2017-03/ILG_Report.pdf

Government of Nepal [GoN]. (1956). Education in Nepal. Kathmandu: The Bureau of Publications College of Education.

Government of Nepal [GoN]. (1999). Local Self Governance Act 2055. Kathmandu: Author.

Government of Nepal. (2010 [2066]. Public Service Commission Act, 2066 (2010). Kathmandu: Author

Government of Nepal [GoN]. (2012). Technical and Vocational Education and Training Policy, 2012. Kathmandu. Author.

Government of Nepal [GoN]. (2015). Constitution of Nepal. Kathmandu: Author.

Government of Nepal [GoN]. (2016). Industrial enterprise Act, 2073. Kathmandu, Nepal: Author

Government of Nepal [GoN]. (2019, October 19). Setting up a business in Nepal. Retrieved from the Official Portal of Government of Nepal: http://nepal.gov.np:8080/National Portal/view page $? \mathrm{id}=96$

Guile, D., \& Griffiths, T. (2001). Learning through work experience. Journal of Education and Work, Vol. 14, No. 1, 2001, 14(1), 113-131.

International Labour Organization [ILO]. (2004). The informal economy and workers in Nepal. Kathmandu: Author.

International Labour Organization [ILO]. (2015). Jobs and skills for youth: review of policies for youth employment of Nepal. Geneva: Author.

Johanson, R. (2009). A review of national training funds. Social Protection Discussion Papers and Notes 52187. The World Bank.

Kafle, A. P. (2007). Workforce development in Nepal: Policies and practices. Tokyo: Asian Development Bank [ADB].

Kyndt, E.; Dochy, F. \& Nijs, H. (2009). Learning conditions for non-formal and informal workplace learning. Journal of Workplace Learning, 21(5). 369-383.

Lama, S. (2016). Nepalese society in response to TEVT programs. Himalayan Journal of Sociology \& Anthropology, VII, 155-174.

Ministry of Culture, Tourism and Civil Aviation [MoCTCA]. (2015). Tourism employment survey 2014. Kathmandu: Author.

Ministry of Education [MoE]. (2018). Education in figure 2017: At a glance. Kathmandu: Author.

Ministry of General Administration [MoGA]. (2014). The Nepal civil service and restructuring of the 
state. Kathmandu: Author.

Ministry of Information and Communication [MoIC]. (2015). Information and communication technology policy 2072. Kathmandu: Author.

Ministry of Labour and Employment [MoLE]. (2014). National Employment Policy 2071. Kathmandu, Nepal: Author.

Ministry of Labour and Employment [MoLE]. (2017). Labour Act 2074 [2017]. Kathmandu, Nepal: Author.

Ministry of Finance [MoF]. (2018). Economic Survey 2017/18. Kathmandu: Author.

National Skill Testing Board [NSTB] (2018). Retrieved December 23, 2018, from National Skill Testing Board [NSTB]: https://www. nstb.org.np

Public Service Commission [PSC] (2018). Fifty ninth Annual Report. Kathmandu: Author.

Regmi, K. D. (2009). Recognition, validation and certification of non-formal and informal learning: A prospects for lifelong learning in Nepal. (Unpublished MPhil dissertation). Kathmandu University School of Education, Balkumari, Lalitpur, Nepal.

Sharma, A. (2016). Information Communication Technology Development in Nepal. JRSD. 101 141.

Supporting Economic Transformation [SET]. (2017). Pathways to prosperity and inclusive job creation in Nepal: Manufacturing sector. Kathmandu: Author.

Teachers Service Commission [TSC]. (2019, July 28). Scope of the work. Retrieved from Government of Nepal Teachers Service Commission [TSC]: https://www.tsc.gov.np/karye

The Asia Foundation. (2012). A guide to government in Nepal: Structures, functions and practices.Kathmandu: Himal Kitab Pvt. Ltd.
TU-Service Commission. (2019, October 20). Home. Retrieved from TU-Service Commission: http://www.tuservicecommission.edu.np

United Nations Development Program [UNDP]. (2019, October 20). NGOs and CSOs: A note on terminology. Retrieved from United Nations Development Program: https://www.undp.org/ content/dam/china/docs/Publications/UNDP CH03\%20Annexes.pdf

Upadhyay, K. (1987). Factors associated with occupational socialization in Nepal. Occasional Papers in Sociology and Anthropology, 1, 94 104.

World Bank. (2019). The World Development Report 2019: The changing nature of the work. Washington DC. Author. 